\title{
Efficacy of Plant Extracts and Chemicals against Ascochyta phaseolorum, Causal Agent of Ascochyta Blight of Vigna anguiculata (L.) Walp.
}

\author{
B.K. Namriboi ${ }^{1^{*}}$, R.K. Tombisana Devi ${ }^{1}$, Dipali Majumder ${ }^{1}$, \\ N.S. Azad Thakur ${ }^{1}$ and L. Hemochandra ${ }^{2}$
}

${ }^{1}$ School of Crop Protection, ${ }^{2}$ School of Social Sciences, College of Post-Graduate Studies, Central Agricultural University (Imphal), Umiam, Meghalaya - 793103, India

*Corresponding author

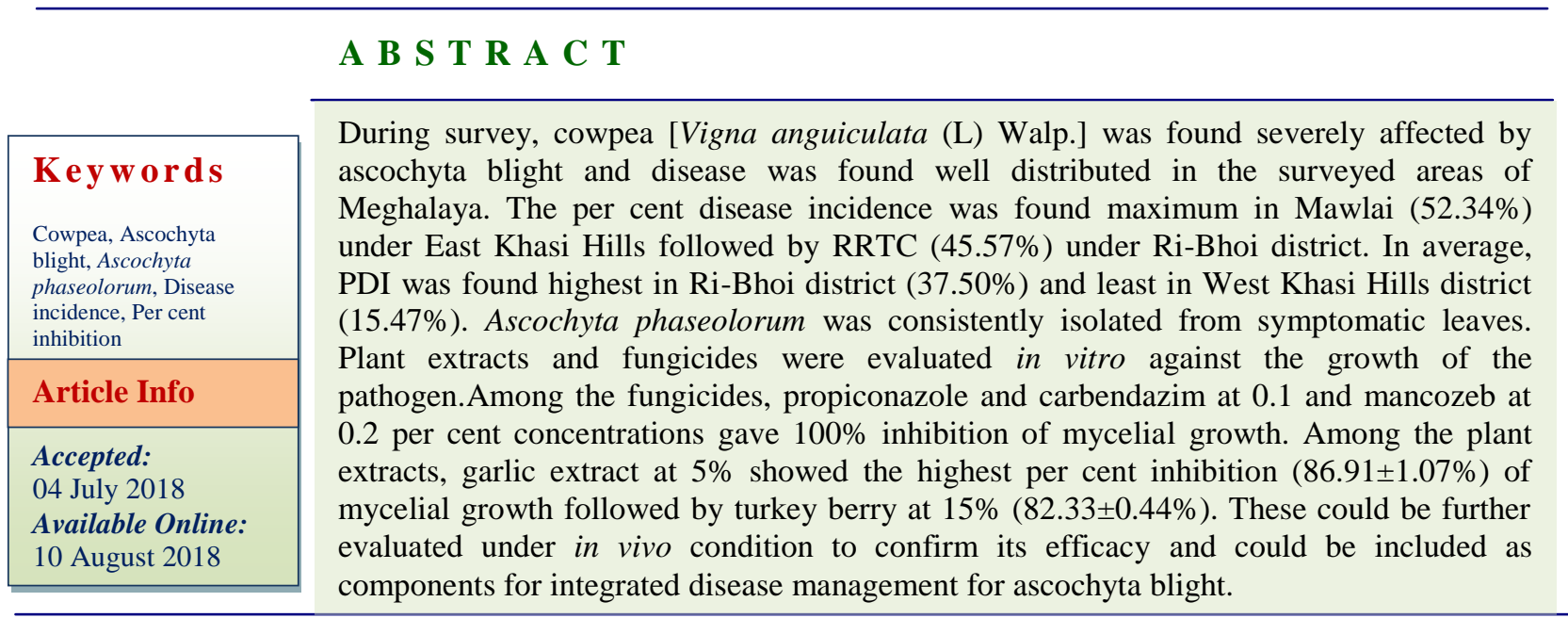

\section{Introduction}

Cowpea [Vigna anguiculata (L.) Walp.] synonymous as lobia, barbati and black eyed pea is assumed to be the principal ancient pulse crop of India. Cowpea grain provides a cheap and nutritious food for relatively poor urban communities. They are source of protein (22-24\%), calcium (0.08-0.11\%), iron $(0.005 \%)$ and essential amino acids (Lysine, leucine and phenylalanine) (Tiwari and Shivhare, 2016). It leaves $30-40 \mathrm{~kg} \mathrm{~N} / \mathrm{ha}$ in the soil for the succeeding crop. The share to world production cowpea dry was 8.45 million metric tons (Singh, 2011). Ascochyta blight is a major disease of cowpea (and many other legumes) under humid conditions often devastating, causing extensive defoliation (Singh and Allen, 2006). Ascochyta blight causes more than 50 per cent or 75 per cent of yield loss in pea (Salam et al., 2011). A wide variability of French bean, cowpea and Indian bean is found in the various parts of the NE region (Asati and Yadav, 2009). Prevailing 
weather conditions in this region is very favorable for the occurrence and disease severity. Until now, little effort has been directed towards the occurrence and management of ascochyta blight in this area. In the present study, attempt has been made to ascertain the occurrence of ascochyta blight on cowpea in Meghalaya and efficacy of locally available plant extracts and fungicides were evaluated for their efficacy against A.phaseolorum.

\section{Materials and Methods}

Survey and assessment of incidence of cowpea ascochyta blight

Surveys were conducted in East Khasi hills, West Khasi hills and Ri-Bhoi districts of Meghalaya during July to August 2017. The leaves per cent disease incidence was assessed by collecting leaves from randomly selected cowpea plants per field surveyed, applying standard 0-9 grade disease rating scale (Mayee and Datar, 1986) as detailed below.

Based on numerical ratings or scale observed per cent disease index (PDI) was calculated using the formula given below:

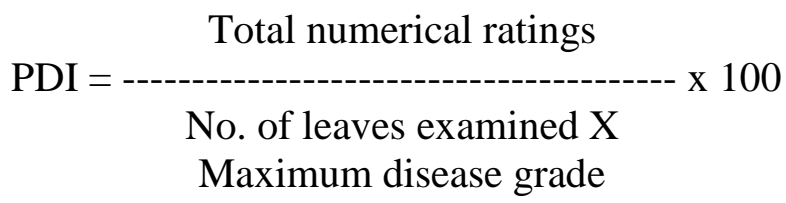

Samples collection, isolation and maintenance of $A$. phaseolorum isolates

The leaves showing typical leaf blight symptoms collected from various places of Meghalaya were brought to the laboratory. The selected infected leaf samples were cut into small pieces from the advancing margins of lesions and the healthy portions. The pieces were surface sterilized with $1 \%$ sodium hypochlorite for one minute followed by three serial washing with sterile distilled water. Surface sterilized leaf bits were then aseptically plated on solidified and cooled PDA (Potato Dextrose Agar) medium in 90 $\mathrm{mm}$ Petri plates under aseptic conditions of Laminar-air-flow cabinet. Inoculated plates were incubated at $27 \pm 1^{\circ} \mathrm{C}$ for seven days. Developing fungal colonies were purified by hyphal tip cut method to obtain pure culture of the isolates. The pathogen was identified by comparing with the cultures in the laboratory and relevant literatures. The fungal isolates were then sub cultured periodically and preserved in PDA slants at $4^{\circ} \mathrm{C}$.

\section{Pathogenicity test}

Pathogenicity test was done on detached healthy leaves of Vigna unguiculata, leaves were surfaced sterilized with $1 \%$ sodium hypochlorite solution followed by rinsing in sterile distilled water 2-3 times and then airdried. Leaves were placed in chambers lined with moist filter paper and wounded by pressing slightly with a pipette tip, and $5 \mathrm{~mm}$ disks of actively growing mycelium (5 days old) were applied on the wounded leaves. Each of the leaf were moistened with wet balls of absorbent cotton wool to create a humid condition and incubated at room temperature for 7 days and observed for disease appearance. Controls were inoculated only with PDA disks. The pathogen was re-isolated from lesions developed on the cowpea leaves.

\section{In vitro evaluation of botanicals (plant extracts) and fungicides against $A$. phaseolorum}

Several plant extracts / botanicals and fungicides have been found antifungal against many Ascochyta spp. Therefore, four botanicals and four fungicides reported earlier as effective against many phytopathogens and which are locally available were evaluated for their biopesticidal effects on growth of 
pathogen applying poisoned food technique (Nene and Thapliyal, 1979) and using PDA as basal medium. The plant extracts and chemicals that were used are given in Table 1 .

\section{Preparation of plant extracts}

Aqueous leaf extracts of the test botanicals were prepared by taking $100 \mathrm{gm}$ of the desired plant material and washing them two to three times in running tap water. Then they were subjected to washing again thrice with sterile distilled water and air dried and crushed in $100 \mathrm{ml}$ distilled (w/v). The crushed extracts were squeezed through two layers of muslin cloth to extract the juice and further filter it through Whatman No. 1 filter paper. The filtrate was centrifuge at $15,000 \mathrm{rpm}$ for $10 \mathrm{mins}$. The supernatant was sterilized finally through bacteria proof membrane syringe filter $(0.22 \mu)$ under laminar air flow. The final clear extracts prepared was the standard plant extracts of $100 \%$ concentration and were stored at $4^{\circ} \mathrm{C}$ in refrigerator.

\section{Poisoned food technique}

An appropriate quantity of each plant extract $(100 \%)$ and fungicides was mixed thoroughly with autoclaved and cooled $\left(40^{\circ} \mathrm{C}\right)$ PDA medium in conical flasks (250 $\mathrm{ml}$ cap.) to obtain desired concentrations. The plates containing PDA without any plant extract was maintained as untreated control. Upon solidification of PDA, all the plates were aseptically inoculated by placing in the centre a $5 \mathrm{~mm}$ mycelial disc obtained from a five days old actively growing pure culture. All these plates were then incubated at $27 \pm 1^{\circ} \mathrm{C}$. Three replications were maintained for each treatment.

The mean colony growth of the test fungus was recorded when the control plate achieved full growth. The mean mycelial growth and standard deviation were calculated as described below. Percentage inhibition (I) of the pathogen was calculated by following the formula described by Vincent (1927):

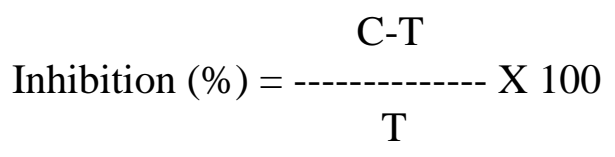

Where,

$\mathrm{I}=$ per cent inhibition of mycelial growth,

$\mathrm{C}=$ Growth in control plate $(\mathrm{cm})$ and

$\mathrm{T}=$ Growth in treated plate $(\mathrm{cm})$

\section{Results and Discussion}

Survey and assessment of incidence of cowpea ascochyta blight

A survey was conducted at different localities under three districts of Meghalaya for assessing the disease incidences ascochyta blight on cowpea, the details of which are mentioned in (Table 2). The ascochyta blight disease was found well distributed in all surveyed areas. Highest disease incidence was recorded at Mawlai (52.34\%) under East Khasi Hills, followed by RRTC (45.57\%) under Ri-Bhoi district. In average, disease incidence was found highest in Ri-Bhoi district $(37.50 \%)$, followed by East Khasi Hills $(30.85 \%)$ and least in West Khasi Hills district $(15.47 \%)$.

\section{Sample collection, isolation and maintenance of $A$. phaseolorum isolates}

The affected plant parts were collected and standard tissue isolation technique was followed to obtain the pathogen causing ascochyta blight in cowpea (Figure 1). A globose light brown pycindia and numbers of hyaline pycnidiospores was observed on microscopic dissection of the disease samples (Figure 2A, B and C). On repeated isolation, it was found that $A$. phaseolorum was 
consistently associated with ascochyta blight of cowpea. The purified pathogen culture was sub-cultured periodically on PDA slants and stored in refrigerator at $4^{\circ} \mathrm{C}$.

\section{Pathogenicity test}

Pathogenicity was carried out by inoculating $5 \mathrm{~mm}$ disks of actively growing mycelium on the healthy leaves of Vigna unguiculata which was wounded by pressing slightly with a sterile pipette tip and maintained in a moist chamber. Seven days after inoculation irregular circular pale lesions with grey centre and less prominent zonation of spots appeared on inoculated leaves (Figure 3). The pathogen was found similar on re-isolation from these artificially infected leaves.

In vitro efficacy of plant extracts and fungicides on growth of $A$. phaseolorum

Four different plant extracts and four fungicides were evaluated for their efficacies on mycelium growth of $A$. phaseolorum at different concentrations by following poisoined food technique (Figure 4). The per cent inhibition was worked out when the mycelium growth of the pathogen in control plate cover full growth. The data obtained were statistically analysed and presented in Table 3.

\section{Survey and assessment of incidence of cowpea ascochyta blight}

\begin{tabular}{|c|c|}
\hline Rating scale & Description \\
\hline 0 & No symptoms on the leaf. \\
\hline 1 & Small, irregular brown spots covering one percent or less of the leaf area. \\
\hline 3 & $\begin{array}{l}\text { Small, irregular, brown spots with concentric rings covering 1-10 per cent } \\
\text { of the leaf area. }\end{array}$ \\
\hline 5 & $\begin{array}{l}\text { Lesions enlarging, irregular, brown with concentric rings covering 11-25 } \\
\text { per cent of the leaf area. }\end{array}$ \\
\hline 7 & $\begin{array}{l}\text { Lesions coalescing to form irregular brown patches with concentric rings } \\
\text { covering } 26-50 \text { percent of the leaf area. }\end{array}$ \\
\hline 9 & $\begin{array}{l}\text { Dark brown patches lesion with concentric rings covering } 51 \text { percent or } \\
\text { more of the leaf area. }\end{array}$ \\
\hline
\end{tabular}

Table.1 Treatments of botanicals and fungicides

\begin{tabular}{|l|l|l|l|l|}
\hline Sl. No. & Treatments & Part to be used & Concentration (\%) \\
\hline 1 & Garlic & (Allium sativum) & Clove & 5 \\
\hline 2 & Ginger & (Zingiber officinale) & Rhizome & 15 \\
\hline 3 & Turmeric & (Curcuma longa) & Rhizome & 15 \\
\hline 4 & Turkey berry & (Solanum torvum) & Leaf & 15 \\
\hline 5 & Propiconazole & (Tilt 25 EC) & & 0.1 \\
\hline 6 & Carbendazim & (Bavistin 50\% WP) & & 0.1 \\
\hline 7 & $\begin{array}{l}\text { Copper } \\
\text { hydroxide }\end{array}$ & $\begin{array}{l}\text { (Kocide } 2000 \\
\text { 35\% WG) }\end{array}$ & 0.2 \\
\hline 8 & Mancozeb & (Indofil M-45 75\% WP) & & 0.2 \\
\hline 9 & Control & Media without plant extract/chemicals & \\
\hline
\end{tabular}


Table. 2 Per cent disease incidence (PDI) of ascochyta blight in various regions of Meghalaya

\begin{tabular}{|c|c|c|c|}
\hline District & Locality & $\begin{array}{l}\text { Disease Incidence } \\
(\%)\end{array}$ & $\begin{array}{l}\text { Mean Disease } \\
\text { Incidence }(\%)\end{array}$ \\
\hline \multirow[t]{4}{*}{ Ri-Bhoi } & Umiam, & 44.72 & \multirow[t]{4}{*}{37.5} \\
\hline & Mawpun Kshaid & 29.72 & \\
\hline & RRTC & 45.57 & \\
\hline & Syadrit & 30 & \\
\hline \multirow{4}{*}{$\begin{array}{l}\text { West Khasi } \\
\text { Hills }\end{array}$} & Nongstoin & 40.57 & \multirow[t]{4}{*}{15.47} \\
\hline & Riangdo & 0 & \\
\hline & Balat & 0 & \\
\hline & Mairang & 21.34 & \\
\hline \multirow{4}{*}{$\begin{array}{l}\text { East Khasi } \\
\text { Hills }\end{array}$} & Mawlai & 52.34 & \multirow[t]{4}{*}{30.85} \\
\hline & Malki & 33.33 & \\
\hline & Upper Shillong & 37.74 & \\
\hline & Sohryngkham & 0 & \\
\hline
\end{tabular}

Table.3 Efficacy of plant extracts and fungicides against A. phaseolorum

\begin{tabular}{|l|l|l|l|l|}
\hline $\begin{array}{l}\text { Sl. } \\
\text { No. }\end{array}$ & Treatments & $\begin{array}{l}\text { Concentratio } \\
\mathbf{n}(\mathbf{\%})\end{array}$ & $\begin{array}{l}\text { Mean colony } \\
\text { diameter }(\mathbf{c m})\end{array}$ & $\begin{array}{l}\text { Per cent } \\
\text { Inhibition }\end{array}$ \\
\hline 1 & Garlic & 5 & $1.18 \pm 0.09(1.08)$ & $\begin{array}{l}86.91 \pm 1.07 \\
(9.32)\end{array}$ \\
\hline 2 & Ginger & 15 & $3.28 \pm 0.07(1.81)$ & $\begin{array}{l}63.58 \pm 0.86 \\
(7.97)\end{array}$ \\
\hline 3 & Turmeric & 15 & $4.38 \pm 0.06(2.09)$ & $\begin{array}{l}51.37 \pm 0.69 \\
(7.16)\end{array}$ \\
\hline 4 & Turkey berry & 15 & $1.59 \pm 0.03(1.24)$ & $\begin{array}{l}82.33 \pm 0.44 \\
(9.07)\end{array}$ \\
\hline 5 & Propiconazole & 0.1 & $0.00 \pm 0.0(0.70)$ & $\begin{array}{l}100.00 \pm 0.00 \\
(10.00)\end{array}$ \\
\hline 6 & Carbendazim & 0.1 & $0.00 \pm 0.0(0.70)$ & $\begin{array}{l}100.00 \pm 0.00 \\
(10.00)\end{array}$ \\
\hline 7 & Copper hydroxide & 0.2 & $2.69 \pm 0.04(1.64)$ & $\begin{array}{l}70.15 \pm 0.48 \\
(8.37)\end{array}$ \\
\hline 8 & Mancozeb & 0.2 & $0.00 \pm 0.00(0.70)$ & $\begin{array}{l}100.00 \pm 0.00 \\
(10.00)\end{array}$ \\
\hline 9 & Control & - & $9.00 \pm 0.00(3.00)$ & $\begin{array}{l}0.00 \pm \\
0.00(0.70)\end{array}$ \\
\hline
\end{tabular}

(Note: Values within the parentheses indicate square root transformed values) 
Fig.1 Typical ascochyta blight symptoms on cowpea leaves in field

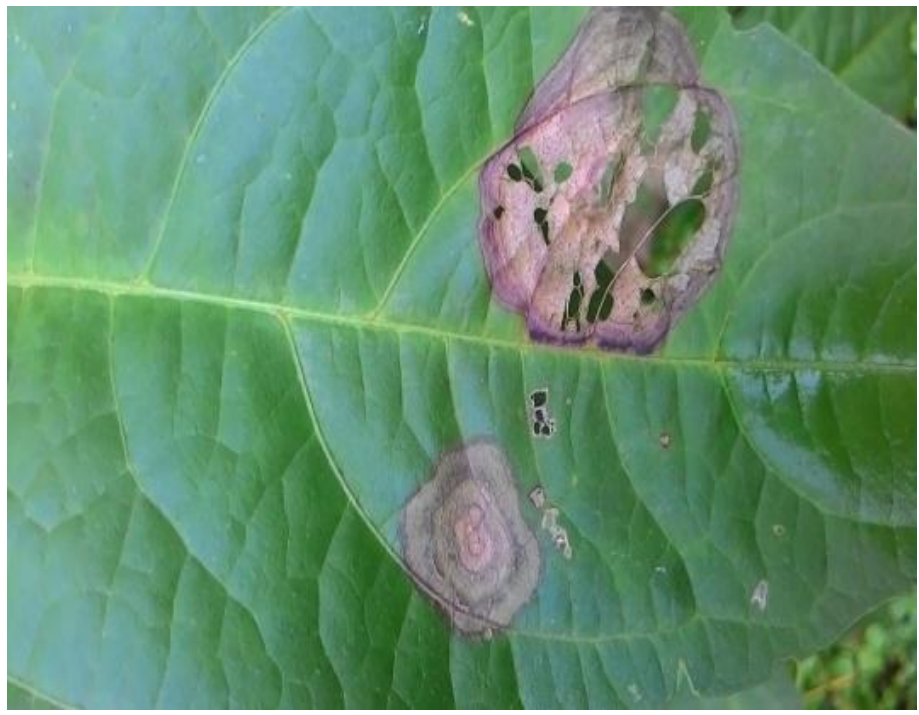

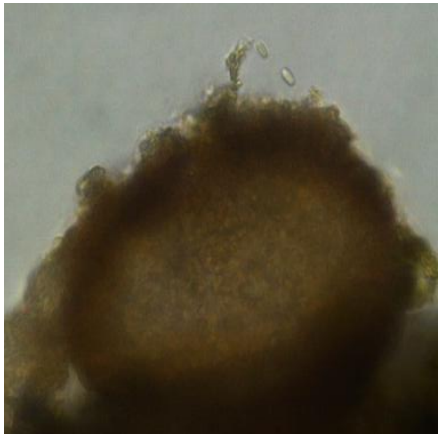

Fig.2 (A) Pycnidium (40X)

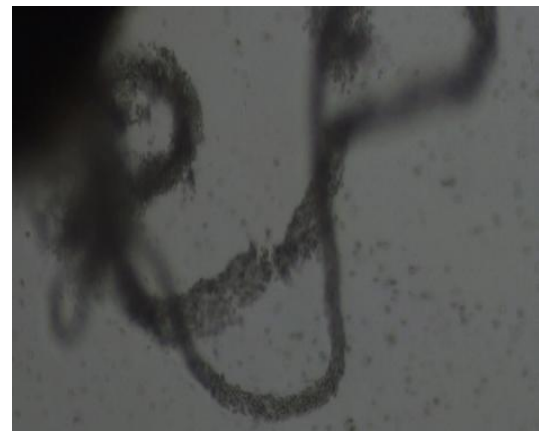

Fig.2 (B) Pycnidiospores extruding from pycnidium $(10 \mathrm{X})$

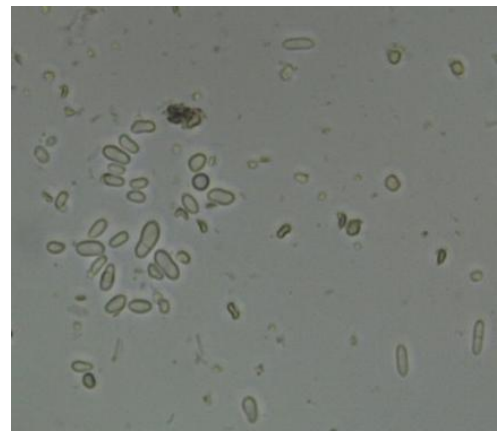

Fig.2 (C) Pycnidiospores (40X)

Fig.3 Disease symptoms on artificial inoculation of A.phaseolorum on cowpea leaves

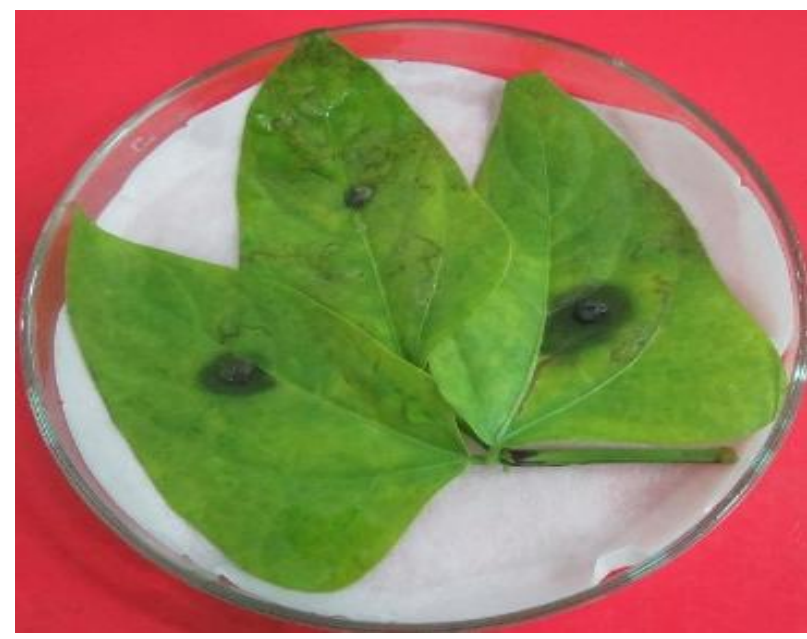




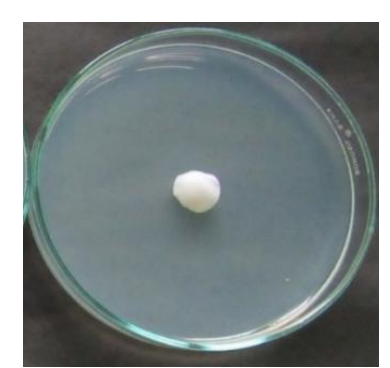

Garlic 5\%

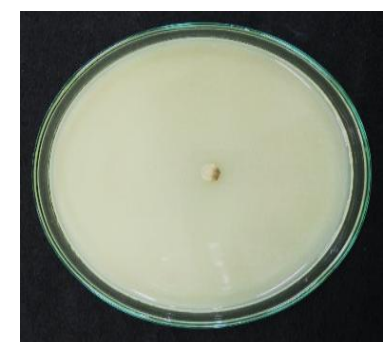

Mancozeb 0.2\%

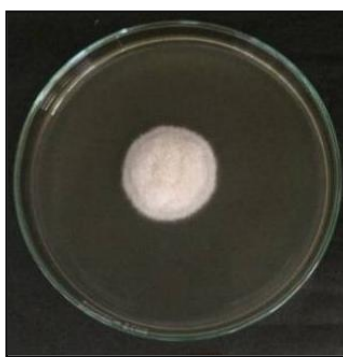

Ginger15\%

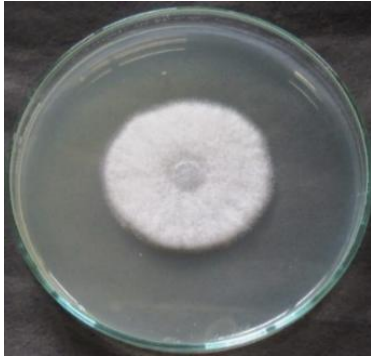

Turmeric15\%

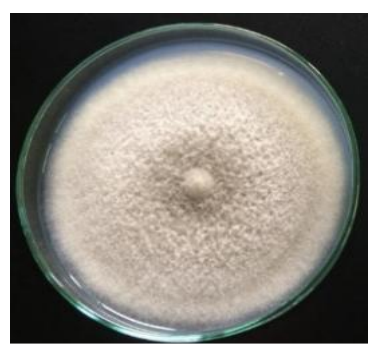

\section{Control}

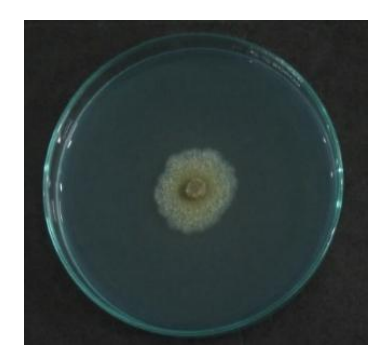

Copper hydroxide $0.2 \%$

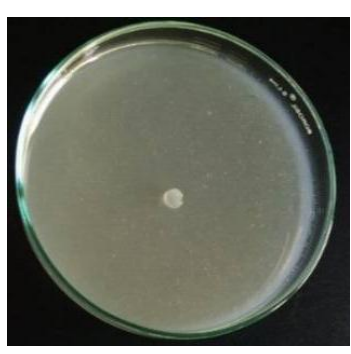

Carbendazim 0.1\%

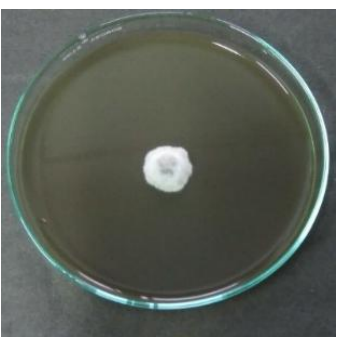

Turkey berry15\%

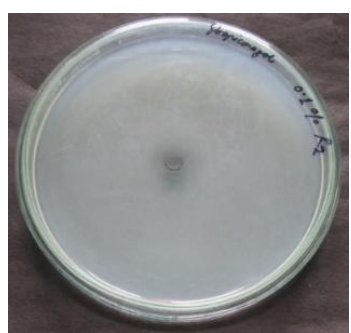

Propiconazole 0.1\%

Fig.4 In vitro efficacy of different plant extracts and fungicides at different concentrations on growth of A. phaseolorum 
Plant extracts displayed varying degrees of effectiveness against $A$. phaseolorum at different concentrations. The study showed that the garlic clove extract at $5 \%$ potentially inhibited $(86.91 \%)$ the growth of the pathogen followed by extracts of turkey berry at $15 \%(82.33 \%)$, ginger $15 \% \quad(63.58 \%)$ and turmeric $15 \%(51.37 \%)$.

Among the four different fungicides tested against $A$. phaseolorum, it was found that propiconazole and carbendazim each at 0.1 per cent concentration gave $100 \%$ inhibition of mycelial growth. However, mancozeb at 0.2 per cent concentration could inhibit $100 \%$ while copper hydroxide showed $70.15 \%$ inhibition at 0.2 per cent concentration.

\section{Survey and assessment of incidence of cowpea ascochyta blight}

The disease was found well distributed in all surveyed areas during the month of July and August. Highest disease incidence was recorded at Mawlai (52.34\%) under East Khasi Hills, followed by RRTC (45.57\%) under Ri-Bhoi district. In average, disease incidence was found highest in Ri-Bhoi district $(37.50 \%)$, followed by East Khasi Hills $(30.85 \%)$ and least in West Khasi Hills district $(15.47 \%)$.

The present finding is in agreement with those of Sutton and Waterston (1966) who reported that $A$. phaseolorum was severe in rainy seasons and had caused considerable losses to pulses in mountainous regions of the Punjab and Rhodesia. Similarly, Singh and Sharma (1998) observed that the disease occurs at all physiological stages ranging from seedling to maturity and Tadesse et al., (2017) also observed that the disease was found more prevalent during flowering/ pod setting stage in surveyed fields of Ethiopia and recorded disease incidence of chickpea blight ranged from 0 to $46.6 \%$.
In vitro efficacy of plant extracts and fungicides on growth of $A$. phaseolorum

Out of four plant extracts and fungicides evaluated for their efficacy against the growth of $A$. phaseolorum, garlic clove at $5 \%$ gave maximum average inhibition (86.91\%) of mycelial growth. This finding was on par with the findings of Jargees et al., (2010) who reported that plant extracts of garlic have an inhibitory activity at 2,4 , and $6 \mathrm{~g} / \mathrm{l}$ concentrations against $A$. rabiei in vitro. The fungal property of garlic might be due to presence of sulphur compounds such as ajoene and allyl propyl on the growth of pathogen. In the present investigation leaf extracts of turkey berry at $15 \%(82.33 \%)$ was found effective against growth of $A$. phaseolorum. The effectiveness of turkey berry might be due to the presence of alkaloids. However, ginger 15\% (63.58\%) and turmeric $15 \%(51.37 \%)$ also displayed satisfactory effect. The efficacy of turkey berry for its antagonistic potential against $A$. phaseolorum was found next to garlic. The fungicides propiconazole and carbendazim each at 0.1 per cent concentration gave $100 \%$ inhibition of mycelial growth. However, mancozeb and copper hydroxide showed $100 \%$ and $70.15 \%$ inhibition at 0.2 per cent concentration respectively. The present findings were in agreement with Pande et al., (2009) who reported that benomyl and carbendazim were effective against ascochyta blight. Shtienberg et al., (2006) reported adequate suppression of ascochyta blight using mancozeb and chlorothalonil. Lepcha (2015) further observed that carbendazim and propiconazole at $0.1 \%$ gave $100 \%$ inhibition of A.phaseolorum.

\section{Summary}

The ascochyta blight of cowpea was found well distributed in the surveyed areas of Meghalaya. Disease incidence was found 
maximum in Mawlai (52.34\%) under East Khasi Hills followed by RRTC (45.57\%) under Ri-Bhoi district. In average, disease incidence was found highest in $\mathrm{Ri}$-Bhoi district $(37.50 \%)$ and least in West Khasi Hills district (15.47\%). Ascochyta phaseolorum Sacc. was found to be consistently associated with ascochyta blight of cowpea. The disease was found more prevalent on leaves than stems and pods. Garlic 5\% (86.91 $\pm 1.07 \%)$ showed the highest per cent inhibition of mycelial growth followed by turkey berry $15 \%$ $(82.33 \pm 0.44 \%)$.Fungicides propiconazole and carbendazim at $0.1 \%$ concentration gave $100 \%$ inhibition of mycelial growth and mancozeb at $0.2 \%$ concentration also gave $100 \%$ inhibition.

Ascochyta blight was found to be widely distributed on cowpea in different regions of Meghalaya. The chemical carbendazim and turkey berry plant extracts were found effective in inhibiting the growth and may be further evaluated under in vivo condition to confirm its efficacy and could be included as components for integrated disease management for ascochyta blight.

\section{References}

Asati, B. S. and Yadav, D. S. (2009). Diversity of horticultural crops in north eastern region. ENVIS Bulletin., 12(1): 22-33.

Jargees, M.M., Al-Dulaimy, F., Al-Azawi, A., Al-Amry, S., and Faic. A. (2010). Evaluation of the efficiency of some plant extracts for Ascochyta blight disease control of chickpea. Arab Journal Pl. Protection, 28: 149-155.

Lepcha, H.L. (2006). Studies on Ascochyta Blight of early blight of Beans. M.Sc. (Agri) thesis, submitted to Central Agricultural University, Imphal.
Mayee, C.D. and Datar, V.V. (1986). Phytopathometry. Tech. Bull-1 Marathwada Agric. Univ., Parbhani, Maharashtra.

Nene, Y.L. and Thapliyal, P.N. (1979). Evaluation of fungicides. In: Fungicides in Plant Disease Control. Oxford and IBH Publishing Company, New Delhi, pp. 531-532.

Pande, S., Sharma, M., Kumari, S., Gaur, P.M., Chen, W., Kaur, L., MacLeod, W., Basandrai, A., Basandrai, D., Bakr, A., Sandhu, J. S., Tripathi, H.S., and Gowda, C.L.L. (2009). Integrated foliar diseases management of legumes. Proceeding of International Conference on Grain legumes: Quality Improvement, Value Addition and Trade, Indian Society of Pulses Research and Development, Indian Institute of Pulses Research. pp. 23-28, February 14-16, 2009, Kanpur, India.

Salam, M.U., MacLeod, W., Maling, T., Prichard, I., Seymour, M., and Barbetti, M.J. (2011). A meta-analysis of severity and yield loss from Ascochyta blight on field pea in Western Australia. Australas. Plant Pathol., 40: 591-600.

Shtienberg, D., Kimber, R.B.E., McMurray, L., and Davidson, J.A. (2006). Optimisation of the chemical control of Ascochyta blight in chickpea. Australas. Plant Pathol., 35: 715-724.

Singh, G. and Sharma, Y.R. (1998). Ascochyta blight of chickpea. In IPM System in Agriculture: Pulses; Upadhyay, R.K., Mukherji, K.G., Eds.; Aditya Books Pvt. Ltd.: New Delhi. pp. 163-195.

Singh, R.P. (2011). Status paper on pulses. Department of Agriculture and Corporation, Government of India, Ministry of Agriculture. pp. 3-8.

Singh, S.R. and Allen, D.J. (2006). Cowpea pest and diseases. International Institute 
of Tropical Agriculture, Nigeria. Manual series 2. pp 61.

Sutton, B.C. and Waterston, J.M. (1966). Ascochyta phaseolorum. CMI Descriptions of pathogenic Fungi and Bacteria, 81: 1-2.

Tadesse, M., Turoop, L., and Ojiewo, C.O. (2017) Survey of chickpea (Cicer arietinum L) ascochyta blight
(Ascochyta rabiei Pass.) disease status in production regions of Ethiopia. Plant, 5(1):23-30.

Tiwari, A.K. and Shivhare, A.K. (2016). Pulses in India: Retrospect and Prospects. DPD, 1 (2): 167-171.

Vincent, J.M. (1927). Distortion of fungal hyphae in presence of certain inhibitors. Nat., 159(4051): 850.

\section{How to cite this article:}

Namriboi, B.K., R.K. Tombisana Devi, Dipali Majumder, N.S. Azad Thakur and Hemochandra, L. 2018. Efficacy of Plant Extracts and Chemicals against Ascochyta phaseolorum, Causal Agent of Ascochyta Blight of Vigna anguiculata (L.) Walp. Int.J.Curr.Microbiol.App.Sci. 7(08): 403-412. doi: https://doi.org/10.20546/ijcmas.2018.708.046 